\title{
Acceptability and Keeping Quality of Marmalades and Canned Slices in Heavy Syrup of Mango Cultivars ${ }^{1}$
}

\author{
Evangelina R. de Hernández, Rubén Guadalupe-Luna and \\ Isabel B. de Caloni ${ }^{2}$ \\ ABSTRACT \\ This study evaluated marmalades and slices in heavy syrup of four mango \\ cultivars-Edward, Irwin, Palmer, and Keitt. All varieties gave well over $65 \%$ \\ recovery in pulp available for canning or marmalades. Both products exhibited \\ some browning during storage, particularly in the marmalades, perhaps \\ because of the lower $\mathrm{pH}$, but such browning did not impair their acceptability. \\ The quality and acceptability of both products were good for as long as 12 \\ months.
}

\section{INTRODUCTION}

Fruits preserved in syrup, in the form of bars, jellies, marmalades, and many other ways have a great demand as desserts, specially slices of fruits in heavy syrup.

Lately, commercial orchards of mangoes (Mangifera indica L.) have been established with the various mango varieties of high quality and flavor that the Agricultural Experiment Station has introduced. This work was undertaken as part of the evaluation of the Edward, Irwin, Palmer, and Keitt cultivars.

Mangoes have been elaborated into nectars, chutneys, canned slices, and pickles in different parts of the world. Sherman et al. (6) describe a process for canning mango slices of the Haden, Zill, Joe Welch, and Ah Ping varieties in $40^{\circ}$ Brix syrup heated to $87.8^{\circ} \mathrm{C}$. Mangoes have also been canned in $50^{\circ}$ Brix syrup containing $0.5 \%$ citric acid and heated to $79.4-82.2^{\circ} \mathrm{C}(1)$.

Little or no information is locally available in regard to the elaboration of mangoes into marmalades and slices in heavy syrup.

\section{MATERIALS AND METHODS}

The mangoes used in this study were obtained from an experimental orchard at the Fortuna substation of the Agricultural Experiment Station, located on the southern coast of Puerto Rico. The mangoes were harvested mature green. The fruits were subjected to a hot water treatment

\footnotetext{
${ }^{1}$ Manuscript submitted to Editorial Board November 18, 1980.

${ }^{2}$ Assistant Researcher, Associate Researcher (Horticulturist) and Associate Researcher, respectively, Food Technology Laboratory, Agricultural Experiment Station, Mayagüez Campus, University of Puerto Rico, Río Piedras, P. R.
} 
as described by Pennock et al. (4) and allowed to ripen at ambient temperature.

Only ripe mangoes with a firm texture were used for the preparation of slices and marmalades.

During the course of our study, the different batches of the four varieties of mangoes were also analyzed as fresh fruit. $\mathrm{pH}$, total acidity, soluble solids (as ${ }^{\circ} \mathrm{Brix}$ ) and total and reducing sugars were determined by official AOAC methods (3). Moisture and total solids were determined by drying in a vacuum oven at $60^{\circ} \mathrm{C}$ for $18 \mathrm{~h}$. Vitamin $\mathrm{C}$ was determined by the 2,6 , dichlorophenol indophenol visual titration method (3). Fiber was assayed by a quick method used by the FDA in determining fiber in green beans (2).

\section{CANNING OF MANGO SLICES IN HEAVY SYRUP}

The fruits were hand-peeled and four slices were cut from each fruit; larger slices were further cut in halves. Prior to candying the slices were immersed in a $1 \%$ sodium bicarbonate solution for $20 \mathrm{~min}$. The slices were then rinsed with tap water for removal of the excess of bicarbonate, and drained.

The candying process consisted in placing the slices in boiling $50^{\circ} \mathrm{Brix}$ sugar syrup with a few pieces of cinnamon and a few whole cloves added for flavoring. The slices with the syrup were boiled gently until a $67^{\circ}$ Brix was attained. At this point, heat was turned down and 303 plain tin cans were filled with $364 \mathrm{~g}$ of drained slices and $280 \mathrm{~g}$ of syrup. The syrup was always kept near boiling to insure sterility. The cans with enameled lids were closed, water-cooled and dried before being stored at ambient conditions.

\section{MANGO MARMALADES}

As in the case of the slices, the fruits were hand-peeled and then cut into slices. These were ground in a $\mathrm{Hobart}^{3}$ grinder with a $1.91 \mathrm{~cm}$ dia. die. This gave a mixture of crushed pulp which also contained chunks of mango.

The marmalades were prepared by a procedure similar to the one described in the Preservers Handbook (5): A measured or weighed amount of water ( $185 \mathrm{~g} / \mathrm{lb}$ pulp) was placed in a kettle and heated. The proper amount of 150 Grade Citrus Pectin, Rapid Set (5.75 g/lb pulp) was thoroughly mixed with 5-8 times its weight of granulated sugar taken from the total amount required for the batch. The mixture of pectin and

${ }^{3}$ Trade names in this publication are used only to provide specific information. Mention of a trade name does not constitute a warranty of equipment or materials by the Agricultural Experiment Station of the University of Puerto Rico, nor is this mention a statement of preference over other equipment or materials. 
sugar was stirred into the hot water and allowed to come to a brisk boil to thoroughly dissolve the pectin. It was then boiled vigorously for about one-half minute. The mango pulp with the remaining amount of sugar was added and boiled as vigorously as possible until a $65^{\circ}$ Brix was reached. The amount of a standard tartaric acid solution (1 fl, oz. approx. $.392 \mathrm{oz}$ tartaric acid) calculated to adjust the $\mathrm{pH}$ of the mixture to 3.4 was added and thoroughly mixed by a brisk boil. The steam was turned down and the glass containers filled and capped while hot (above $87.8^{\circ} \mathrm{C}$ ).

The glass containers were allowed to cool before being stored at ambient conditions.

After at least 2 weeks the slices and the marmalades were assessed for quality and chemical composition. This period brings about an equilibrium between the fruit pulp and the surrounding syrup.

TABLE 1.-Fruit size and composition of the four mango varieties

\begin{tabular}{lcccc}
\hline Variety & $\begin{array}{c}\text { Mean weight } \\
\text { of fruits }\end{array}$ & Pulp & Peel & Seeds $^{2}$ \\
\hline Edward & $g$ & $\%$ & $\%$ & $\%$ \\
Irwin & 421.33 & 68.95 & 11.50 & 19.55 \\
Palmer & 259.14 & 65.03 & 16.03 & 18.94 \\
Keitt & 451.81 & 70.20 & 12.68 & 17.12 \\
\hline
\end{tabular}

${ }^{1}$ Pulp-slices.

${ }^{2}$ Seeds-unclean seeds with remaining pulp after slicing.

The quality of the slices and of the marmalades of the four mango varieties was assessed every other month and up to 1 year of storage by a 7 to 13 -member tasting panel. A six-point hedonic scale $(6=$ likes very much; 1=dislikes) was used to measure the organoleptic attributes of appearance, taste, texture, and general acceptability.

Soluble solids, $\mathrm{pH}$, sugars, and total acidity were determined every other month by the methods already mentioned. Total acidity was calculated as citric acid in the mango slices and as tartaric acid in the marmalades. Tartaric acid was used since it was found to give less tartness to the marmalades. Color was measured with a Hunterlab model D-25 color and color difference meter ${ }^{3}$, calibrated with a Hunterlab yellow standard No. $3125(L=55.8, a=18.9, b=33.4)$ for the slices and a Hunterlab yellow standard No. $3130(L=62.3, a=12.2, b=37.2)$ for the marmalades.

\section{RESULTS AND DISCUSSIONS}

Table 1 shows that all varieties yielded well over $65 \%$ of fruit pulp in slices. The Keitt variety produced the highest yield. It also had the largest fruit, with an average weight of $586.66 \mathrm{~g}$. The Irwin variety 
produced the lowest yield and the smallest fruit, with an average weight of $259.14 \mathrm{~g}$. The Edward and Palmer varieties with average fruit weights of $421.33 \mathrm{~g}$ and $451.81 \mathrm{~g}$ gave yields of $68.95 \%$ and $70.20 \%$, respectively. These recoveries are influenced by the size of the fruits and are somewhat

TABLE 2.-Chemical and physical composition of the four mango varieties ${ }^{1}$

\begin{tabular}{lccccccccc}
\hline \multicolumn{1}{c}{ Variety } & ${ }^{\circ}$ Brix & $\mathrm{pH}$ & $\begin{array}{c}\text { Total } \\
\text { acidity }\end{array}$ & Moisture & $\begin{array}{c}\text { Total } \\
\text { solids }\end{array}$ & $\begin{array}{c}\text { Reducing } \\
\text { sugars }\end{array}$ & $\begin{array}{c}\text { Total } \\
\text { sugars }\end{array}$ & $\begin{array}{c}\text { Ascorbic } \\
\text { acid }\end{array}$ & Fiber \\
\hline Irwin & 16.0 & 4.33 & 0.21 & 84.35 & 15.65 & 5.49 & 13.76 & 32.08 & 55 \\
Edward & 21.2 & 4.51 & .22 & 78.98 & 21.02 & 3.61 & 17.58 & 47.51 & 48 \\
Palmer & 20.5 & 4.54 & .19 & 78.89 & 21.11 & 4.56 & 18.58 & 39.92 & 38 \\
Keitt & 21.5 & 3.90 & .55 & 77.58 & 22.42 & 5.48 & 18.07 & 6.76 & 55 \\
\hline
\end{tabular}

${ }^{1}$ Each value represents the mean of at least 5 different lots.

TABLE 3.-Chemical and physical analyses of mango marmalades during storage

\begin{tabular}{|c|c|c|c|c|c|c|c|c|c|}
\hline \multirow{2}{*}{ Variety } & \multirow{2}{*}{$\begin{array}{l}\text { Days in } \\
\text { storage }\end{array}$} & \multirow{2}{*}{${ }^{\circ}$ Brix } & \multirow{2}{*}{$\mathrm{pH}$} & \multirow{2}{*}{$\begin{array}{l}\text { Total } \\
\text { acidity }\end{array}$} & \multirow{2}{*}{$\begin{array}{l}\text { Reducing } \\
\text { sugars }\end{array}$} & \multirow{2}{*}{$\begin{array}{l}\text { Total } \\
\text { sugars }\end{array}$} & \multicolumn{3}{|c|}{ Color $^{1}$} \\
\hline & & & & & & & $L$ & $a$ & $b$ \\
\hline & & & & $\%$ & $\%$ & $\%$ & & & \\
\hline \multirow[t]{7}{*}{ Edward } & Fresh & 62.0 & 3.50 & 0.396 & 21.16 & 61.81 & 36.35 & 5.60 & 24.14 \\
\hline & 60 & 61.8 & 3.49 & .395 & 28.39 & 62.24 & 33.99 & 6.87 & 22.26 \\
\hline & 120 & 62.2 & 3.49 & .421 & 33.94 & 61.18 & 33.06 & 7.08 & 21.76 \\
\hline & 180 & 62.2 & 3.51 & .427 & 38.78 & 62.27 & 33.00 & 7.99 & 21.60 \\
\hline & 240 & 63.2 & 3.51 & .423 & 40.22 & 62.70 & 30.95 & 7.58 & 20.15 \\
\hline & 300 & 62.8 & 3.45 & .418 & 42.55 & 59.87 & 30.08 & 8.00 & 19.48 \\
\hline & 360 & 63.2 & 3.37 & .421 & 45.00 & 61.73 & 29.24 & 7.92 & 18.94 \\
\hline \multirow[t]{7}{*}{ Irwin } & Fresh & 63.8 & 3.40 & 0.353 & 37.79 & 64.30 & 33.06 & 1.08 & 22.18 \\
\hline & 60 & 64.2 & 3.40 & .340 & 43.52 & 65.40 & 31.55 & 1.42 & 20.95 \\
\hline & 120 & 64.2 & 3.43 & .361 & 48.05 & 64.25 & 28.02 & 5.04 & 18.56 \\
\hline & 180 & 64.8 & 3.43 & .368 & 50.64 & 63.62 & - & - & - \\
\hline & 240 & 64.8 & 3.42 & .352 & 50.49 & 63.52 & 24.90 & 5.23 & 16.18 \\
\hline & 300 & 65.6 & 3.39 & .357 & 52.09 & 62.75 & 23.52 & 5.18 & 15.10 \\
\hline & 360 & 64.4 & 3.38 & .369 & 53.77 & 62.53 & 23.48 & 6.27 & 15.04 \\
\hline \multirow[t]{7}{*}{ Palmer } & Fresh & 63.8 & 3.49 & 0.399 & 37.58 & 57.85 & 33.51 & 4.23 & 22.40 \\
\hline & 60 & 62.6 & 3.45 & .409 & 36.87 & 59.71 & 32.72 & 6.58 & 21.60 \\
\hline & 120 & 62.8 & 3.48 & .420 & 43.19 & 62.23 & 33.00 & 7.50 & 21.94 \\
\hline & 180 & 62.5 & 3.49 & .382 & 42.22 & 59.93 & 30.33 & 7.79 & 19.88 \\
\hline & 240 & 63.1 & 3.40 & .397 & 46.02 & j9.93 & 29.71 & 7.39 & 19.05 \\
\hline & 300 & 62.8 & 3.44 & .394 & 47.45 & 60.45 & 31.15 & 8.54 & 20.37 \\
\hline & 360 & 62.4 & 3.43 & .432 & 47.64 & 57.25 & 30.58 & 7.18 & 19.94 \\
\hline \multirow[t]{6}{*}{ Keitt } & Fresh & 63.2 & 3.40 & 0.560 & 46.89 & 60.96 & 27.82 & 5.16 & 18.14 \\
\hline & 60 & 64.4 & 3.50 & .589 & 51.95 & 64.10 & 26.13 & 5.39 & 16.81 \\
\hline & 120 & 63.4 & 3.49 & .575 & 50.42 & 62.00 & 25.32 & 6.32 & 16.13 \\
\hline & 180 & 63.2 & 3.49 & .544 & 52.20 & 61.00 & 23.78 & 5.85 & 15.08 \\
\hline & 240 & 63.0 & 3.50 & .555 & 52.34 & 60.87 & 23.16 & 5.68 & 14.75 \\
\hline & 360 & 63.1 & 3.49 & .591 & 52.70 & 59.22 & 21.63 & 5.48 & 13.64 \\
\hline
\end{tabular}

${ }^{1}$ Yellow standard No. $3130(L=62.3, a=12.2, b=37.2)$. 
higher than the ones reported by Sherman et al. (6) for fruits of similar weights.

The reported percentage of seeds is not accurate because when four slices are cut from each fruit, an amount of pulp remains attached to the seeds. This pulp can be extracted and utilized in the preparation of mango puree. In a large commercial operation this could very well be another source of raw material.

TABLE 4.-Chemical and physical analyses of mango slices in syrup during storage

\begin{tabular}{|c|c|c|c|c|c|c|c|c|c|}
\hline \multirow{2}{*}{ Variety } & \multirow{2}{*}{$\begin{array}{l}\text { Days in } \\
\text { storage }\end{array}$} & \multirow{2}{*}{${ }^{\circ}$ Brix } & \multirow{2}{*}{$\mathrm{pH}$} & \multirow{2}{*}{$\begin{array}{c}\text { Total } \\
\text { acidity }\end{array}$} & \multirow{2}{*}{$\begin{array}{l}\text { Reducing } \\
\text { sugars }\end{array}$} & \multirow{2}{*}{$\begin{array}{l}\text { Total } \\
\text { sugars }\end{array}$} & \multicolumn{3}{|c|}{ Color ${ }^{1}$} \\
\hline & & & & & & & $L$ & $a$ & $b$ \\
\hline & & & & $\%$ & $\%$ & $\%$ & & & \\
\hline \multirow[t]{7}{*}{ Edward } & Fresh & 67.0 & - & - & - & - & - & - & - \\
\hline & 60 & 59.8 & 4.22 & 175 & 18.65 & 60.02 & 31.53 & 12.88 & 21.02 \\
\hline & 120 & 55.4 & 4.25 & .202 & 19.06 & 54.98 & 33.36 & 14.07 & 22.16 \\
\hline & 180 & 60.4 & 4.34 & .236 & 20.47 & 59.54 & - & - & - \\
\hline & 240 & 58.8 & 4.30 & .172 & 20.58 & 56.83 & 32.15 & 14.14 & 21.26 \\
\hline & 300 & 58.4 & 4.29 & .176 & 21.13 & 56.28 & 31.48 & 13.92 & 20.66 \\
\hline & 360 & 58.8 & 4.30 & .155 & 20.61 & 58.65 & 30.48 & 15.59 & 20.08 \\
\hline \multirow[t]{7}{*}{ Irwin } & Fresh & 67.0 & - & - & - & - & - & - & - \\
\hline & 60 & 56.2 & 4.57 & .116 & 14.14 & 56.42 & 31.55 & 14.02 & 21.09 \\
\hline & 120 & 55.6 & 4.60 & .105 & 14.68 & 56.16 & 30.59 & 13.41 & 20.48 \\
\hline & 180 & 56.8 & 4.60 & .127 & 15.40 & 56.03 & - & - & - \\
\hline & 240 & 56.2 & 4.49 & .124 & 17.00 & 55.77 & 30.57 & 13.64 & 20.28 \\
\hline & 300 & 56.3 & 4.45 & .110 & 16.06 & 55.69 & 30.60 & 13.90 & 20.07 \\
\hline & 360 & 56.0 & 4.49 & .114 & 17.15 & 55.49 & 28.84 & 15.64 & 18.96 \\
\hline \multirow[t]{6}{*}{ Palmer } & Fresh & 67.0 & 4.32 & 0.181 & 12.33 & 54.02 & 37.73 & 13.39 & 25.32 \\
\hline & 60 & 52.2 & 4.39 & .187 & 13.05 & 51.19 & 41.36 & 13.49 & 27.48 \\
\hline & 120 & 56.4 & 4.44 & .166 & 14.12 & 54.55 & - & - & - \\
\hline & 180 & 56.4 & 4.44 & 1.56 & 14.95 & 55.13 & 35.80 & 16.77 & 23.83 \\
\hline & 240 & 55.4 & 430 & .178 & 16.50 & 53.57 & 35.42 & 15.33 & 23.49 \\
\hline & 360 & 55.8 & 4.30 & .201 & 18.79 & 51.44 & 36.41 & 14.22 & 24.11 \\
\hline \multirow[t]{7}{*}{ Keitt } & Fresh & 67.0 & 4.12 & 0.334 & 31.99 & 58.74 & 30.64 & 10.38 & 20.31 \\
\hline & 60 & 58.2 & 4.09 & .353 & 31.68 & 56.69 & 32.86 & 13.12 & 21.73 \\
\hline & 120 & 58.9 & 4.10 & .317 & 32.75 & 57.99 & 30.46 & 12.60 & 19.98 \\
\hline & 180 & 55.9 & 4.12 & .334 & 30.84 & 52.35 & 32.70 & 13.37 & 21.36 \\
\hline & 240 & 55.8 & 4.13 & .342 & 32.83 & 53.75 & 30.88 & 13.04 & 20.24 \\
\hline & 300 & 54.6 & 4.10 & .377 & 34.21 & 52.92 & 28.52 & 12.21 & 18.52 \\
\hline & 360 & 58.7 & 3.90 & .367 & 36.01 & 54.77 & 26.22 & 11.41 & 17.02 \\
\hline
\end{tabular}

${ }^{1}$ Yellow standard No. $3125(L=55.8, a=18.9, b=33.4)$.

Table 2 shows the composition of the four mango varieties. The Keitt variety had the lowest vitamin $\mathrm{C}$ content, while Edward had the highest. The Keitt variety had the highest total acidity. Among the four varieties the Irwin had the lowest soluble solids and the lowest total sugars. The lowest reducing sugars were found in the Edward. The Irwin variety had the lowest total solids.

Tables 3 and 4 show the chemical and physical properties of the 
marmalades and the slices in heavy syrup. In the marmalades, the most marked changes occurred in the reducing sugars, which increased more than one-fold as storage time increased; and in color lightness which decreased as shown by $L$ values. This is also evident when the total color difference $\Delta \mathrm{E}=\sqrt{(\Delta L)^{2}+(\Delta a)^{2}+(\Delta b)^{2}}$ is calculated and plotted (fig. 1). The curves show an increase in total color difference as evidenced by

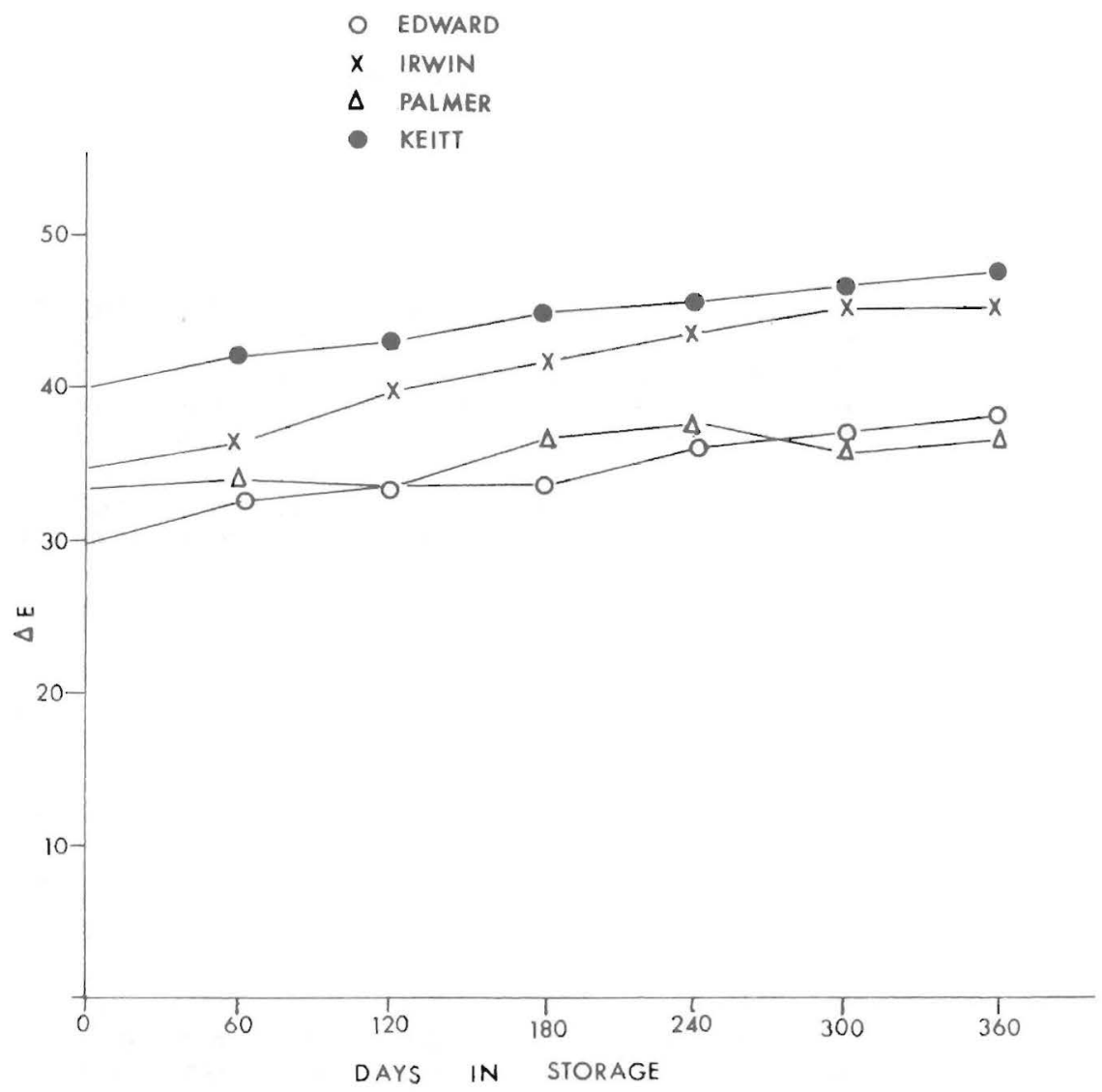

FIG. 1.-Color difference values $(\Delta \mathrm{E})$ of the different mango marmalades during storage.

an increase in the browning discoloration of the samples. The Keitt and Irwin marmalades exhibited the most browning. Neither the total acidity nor the $\mathrm{pH}$ changed appreciably.

In the slices in heavy syrup the most marked changes occurred in the color and in the Brix. The Brix showed a marked reduction in the syrup during the first months, which is due to the stabilization of the slices with the syrup. The color as seen by the $L$ values shows a decrease in lightness. 
This is corroborated when the total color difference is calculated and plotted (fig. 2). The curves demonstrate the same tendency to a less degree as in the marmalades.

Although the reducing sugars increase during storage, as expected, this increase is not as high as in the marmalades.

As in the marmalades, the total acidity and the $\mathrm{pH}$ did not reflect change.

$$
\begin{aligned}
& \text { O EDWARD } \\
& X \text { IRWIN } \\
& \triangle \text { PALMER } \\
& \text { - KEITT }
\end{aligned}
$$

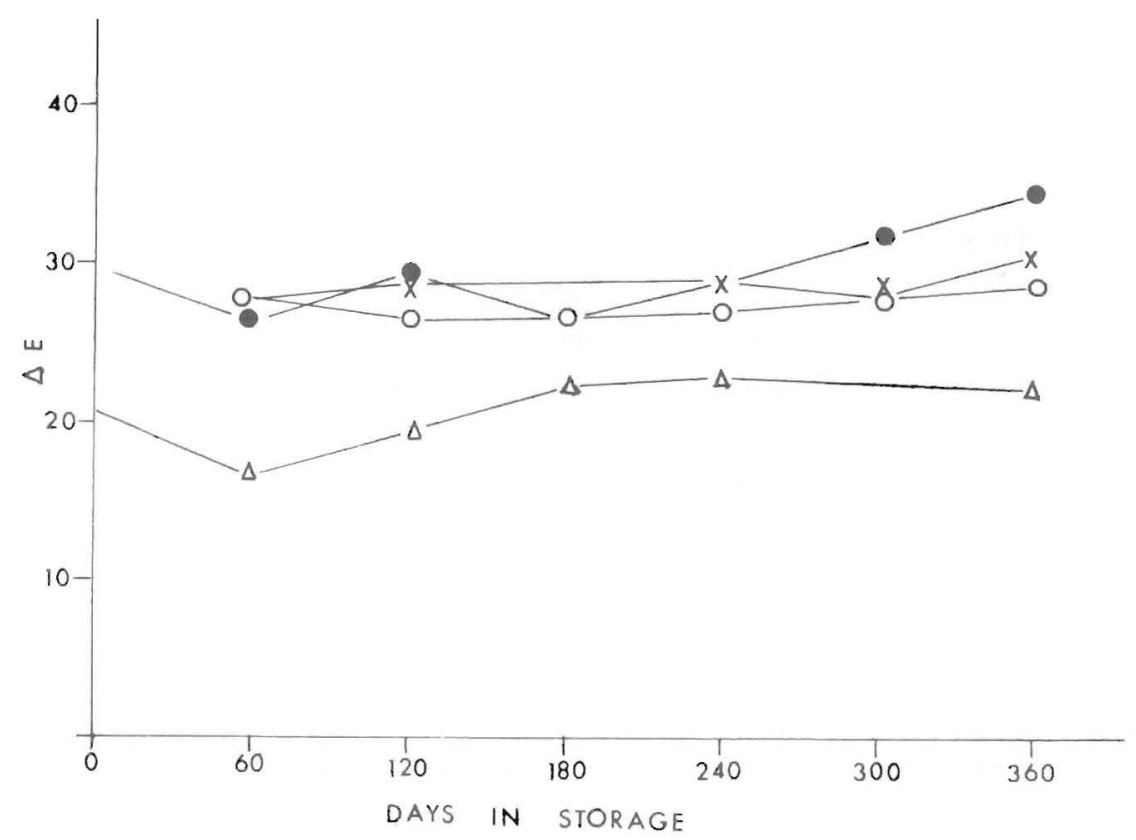

FIG. 2.-Color difference values ( $\Delta \mathrm{E})$ of the different mango slices during storage.

In general, good quality marmalades and slices in heavy syrup, having good acceptability were obtained. The high acceptability of the marmalades as seen in table 5 was maintained for about a year. During the last two months of storage the scores dropped, bringing the acceptability of all the marmalades, except that of Edward, to moderately liked. This drop in score may be due to the increase in browning and the development 
of some off-flavors. The marmalade from the Keitt variety had the greatest drop. The acceptability of the slices in heavy syrup (table 6) was good throughout the year in storage. The Keitt and Palmer varieties were the ones with the greatest drop in score but still remained acceptable.

TABLE 5.-Quality of mango marmalades when fresh and after 12 months

\begin{tabular}{|c|c|c|c|c|c|c|c|c|c|}
\hline \multirow{2}{*}{ Variety } & \multirow{2}{*}{$\begin{array}{l}\text { Days in } \\
\text { storage }\end{array}$} & \multicolumn{2}{|c|}{ Appearance } & \multicolumn{2}{|c|}{ Taste } & \multicolumn{2}{|c|}{ Texture } & \multicolumn{2}{|c|}{$\begin{array}{c}\text { General accepta- } \\
\text { bility }\end{array}$} \\
\hline & & Score $^{1}$ & Rating & Score & Rating & Score & Rating & Score & Rating \\
\hline \multirow[t]{2}{*}{ Edward } & Fresh & 5.4 & Likes & 5.0 & Likes & 4.8 & Likes & 4.9 & Likes \\
\hline & 360 & 5.1 & Likes & 4.7 & Likes & 4.4 & $\begin{array}{l}\text { Likes } \\
\text { Moder- } \\
\text { ately }\end{array}$ & 4.6 & Likes \\
\hline \multirow[t]{2}{*}{ Irwin } & Fresh & 5.2 & Likes & 4.0 & $\begin{array}{l}\text { Likes } \\
\text { Moder- } \\
\text { ately }\end{array}$ & 4.5 & Likes & 3.8 & $\begin{array}{l}\text { Likes } \\
\text { Moder- } \\
\text { ately }\end{array}$ \\
\hline & 360 & j3 & Likes & 4.1 & $\begin{array}{l}\text { Likes } \\
\text { Moder- } \\
\text { ately }\end{array}$ & 4.3 & $\begin{array}{l}\text { Likes } \\
\text { Moder- } \\
\text { ately }\end{array}$ & 4.1 & $\begin{array}{l}\text { Likes } \\
\text { Moder- } \\
\text { ately }\end{array}$ \\
\hline \multirow[t]{2}{*}{ Palmer } & Fresh & 5.3 & Likes & 4.9 & Likes & 4.9 & Likes & 5.0 & Likes \\
\hline & 360 & 5.0 & Likes & 4.2 & $\begin{array}{l}\text { Likes } \\
\text { Moder- } \\
\text { ately }\end{array}$ & 4.7 & Likes & 4.3 & $\begin{array}{l}\text { Likes } \\
\text { Moder- } \\
\text { ately }\end{array}$ \\
\hline \multirow[t]{2}{*}{ Keitt } & Fresh & 5.2 & Likes & 4.9 & Likes & 5.3 & Likes & 5.2 & Likes \\
\hline & 360 & 4.3 & $\begin{array}{l}\text { Likes } \\
\text { Moder- } \\
\text { ately }\end{array}$ & 3.5 & $\begin{array}{l}\text { Likes } \\
\text { Moder- } \\
\text { ately }\end{array}$ & 4.5 & Likes & 3.5 & $\begin{array}{l}\text { Likes } \\
\text { Moder- } \\
\text { ately }\end{array}$ \\
\hline
\end{tabular}

${ }^{1}$ Six-point scale: 6 likes very much; 5 likes; 4 likes moderately; 3 neither likes or dislikes; 2 dislikes a bit; 1 dislikes.

TABLE 6.-Quality of mango slices in heavy syrup when fresh and after 12 months

\begin{tabular}{|c|c|c|c|c|c|c|c|c|c|}
\hline \multirow{2}{*}{ Variety } & \multirow{2}{*}{$\begin{array}{l}\text { Days in } \\
\text { Storage }\end{array}$} & \multicolumn{2}{|c|}{ Appearance } & \multicolumn{2}{|c|}{ Taste } & \multicolumn{2}{|c|}{ Texture } & \multicolumn{2}{|c|}{$\begin{array}{c}\text { General accepta- } \\
\text { bility }\end{array}$} \\
\hline & & Score $^{1}$ & Rating & Score & Rating & Score & Rating & Score & Rating \\
\hline \multirow[t]{2}{*}{ Edward } & Fresh & 5.0 & Likes & 5.2 & Likes & 4.9 & Likes & 4.8 & Likes \\
\hline & 360 & 5.0 & Likes & 4.9 & Likes & 4.6 & Likes & 4.7 & Likes \\
\hline \multirow[t]{2}{*}{ Irwin } & Fresh & 5.3 & Likes & 4.9 & Likes & 4.9 & Likes & 4.9 & Likes \\
\hline & 360 & 5.0 & Likes & 4.7 & Likes & 4.0 & $\begin{array}{l}\text { Likes } \\
\text { moder- } \\
\text { ately }\end{array}$ & 4.6 & Likes \\
\hline \multirow[t]{2}{*}{ Palmer } & Fresh & 5.3 & Likes & 5.2 & Likes & 4.8 & Likes & 5.2 & Likes \\
\hline & 360 & 5.0 & Likes & 4.8 & Likes & 4.8 & Likes & 4.6 & Likes \\
\hline \multirow[t]{2}{*}{ Keitt } & Fresh & 4.5 & Likes & 4.8 & Likes & 4.7 & Likes & 4.7 & Likes \\
\hline & 360 & 4.5 & Likes & 4.2 & $\begin{array}{l}\text { Likes } \\
\text { moder- } \\
\text { ately }\end{array}$ & 4.2 & $\begin{array}{l}\text { Likes } \\
\text { moder- } \\
\text { ately }\end{array}$ & 4.2 & $\begin{array}{l}\text { Likes } \\
\text { moder- } \\
\text { ately }\end{array}$ \\
\hline
\end{tabular}

'Six-point scale: 6 likes very much; 5 likes; 4 likes moderately; 3 neither likes or dislikes; 2 dislikes a bit; 1 dislikes. 


\section{RESUMEN}

Tajadas en almíbar y mermeladas de cuatro variedades de mangoes; Edward, Irwin, Palmer, y Keitt, se prepararon y se evaluaron. Todas las variedades produjeron más de un $65 \%$ de pulpa disponible en forma de tajadas o para mermaladas. Los dos productos reflejaron un obscurecimiento durante el período de almacenamiento. Las mermeladas se obscurecieron más, debido quizás al pH más bajo, pero este cambio no afecta totalmente la aceptabilidad. La buena calidad y la aceptabilidad de ambos productos perduró por 12 meses en almacén.

\section{LITERATURE CITED}

1. Anon., 1953. Canning of mangoes, Food Sci. 3 (1):26.

2. Food and Drug Administration, U.S.A., Standards of Identity, Quality, and Fill of Containers for Canned Foods, Canned Green Beans, 1974.

3. Official Methods of Analysis of the Association of Official Analytical Chemists, 12th ed, Washington, D.C., 1975.

4. Pennock, W. and Maldonado, G., 1962. Hot water treatment of mango fruits to reduce anthracnose decay, J. Agric. Univ. P. R., 46, (4): 272-83.

5. Preservers Handbook, 1956. 6th ed, revised, Sunkist Growers, Ontario, Calif.

6. Sherman, G. D., Sakata, S. and Hamilton, R. A., 1958. Commercial mango canning in Hawaii, Hawaii Univ. Agric. Exp. Stn. Circ. 54. 